\title{
A TÁPLÁLKOZÁS ÉS TESTMOZGÁS KIEMELKEDÓ SZEREPE AZ EGÉSZSÉGES ÉLETMÓDBAN
}

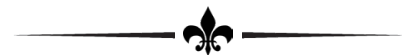

\section{THE PROMINENT ROLE OF DIET AND EXERCISE IN THE HEALTHY LIFESTYLE}

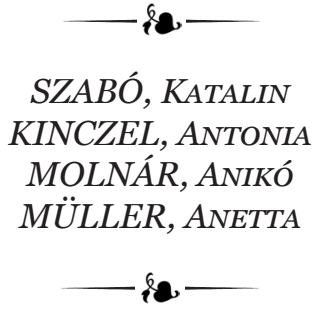

Debreceni Egyetem, Gazdaságtudományi Kar, Sportgazdasági és -Menedzsment Intézet (University of Debrecen, Faculty of Economics and Business, Institute of Sports Management) H-4032 Debrecen, Böszörményi út 138. e-mail: szabo.katalin.degtk@gmail.com

\begin{abstract}
al
Lifestyle-related diseases, such as type 2 diabetes, obesity, cardiovascular or stress-related diseases, or osteoporosis, are well-known to everyone, in the prevention or development of which lifestyle elements such as diet or exercise play a key role. In order to prevent the development of these diseases mentioned above, we should pay enough attention to a healthy lifestyle and prevention. In today's modern world, we already have a wealth of knowledge that contributes largely to the prevention of said diseases, however, many people still struggle with them. An important factor is that regular exercise and a healthy diet help to create a healthier lifestyle and play a protective role against a wide range of diseases.
\end{abstract}

KuLCSSZAVAK: testmozgás, táplálkozás, egészséges életmód

JEL-KódoK (JEL CODES): I10, I12, I19

DOI: https://doi.org/10.20494/TM/8/2/4

\section{BEVEZETÉS - INTRODUCTION}

Elmondható, hogy a mai felgyorsult világban az emberek sokasága szenved valamilyen civilizációs betegségben, melyért erősen felelős a megváltozott életmód (MÜLLER és BÁCSNÉ, 2018). Az emberek túlhajszolt életvitelt folytatnak, helytelenül táplálkoznak, stresszesek és kevés időt fordítanak a rendszeres testmozgásra, relaxációra. Észrevehetjük, hogy a modern kor hatására elkényelmesedtünk, hiszen számos helyre autóval közlekedünk, számos házimunka gépesítve lett, a fiatalok is a szabadban
KEYwORDS: physical activity, healthy diet, healthy lifestyle

való játék helyett az internet világát választják. Az életmódelemek között a táplálkozási szokásaink is megváltoztak (DESHPANDE et al., 2009; SCHWARTZ et al., 2011; GORSKI és ROBERTO, 2015), a kutatások megerősítik, hogy a felgyorsult, rohanó világunkkal együtt jár a gyorséttermi szolgáltatások, a félkész és késztermékek fogyasztásának dominanciája. A táplálkozás és az életmódfüggő betegségek kialakulása között erős kapcsolatot igazoltak (PANYOR, 2019; BERKE et al., 2009), a táplálkozási szokások ugyanakkor a prevenció egyik meghatározó eszközei is lehetnek (NAGY és PÓSFAI, 2013). 
Az életmódelemek kialakításában az elsődleges szocializációs színtér, azaz a család szerepét hangsúlyozza több kutatás akár a táplálkozási (HOLCZER és KISS, 2019), akár a sportolási szokások területén (KÓS és HERPAINÉ LAKÓ, 2019; HERPAINÉ LAKÓ 2010, 2014), melyben a szülői értékrend és az ismeretátadás az egészséges táplálkozásban vagy a sportolási szokások életmód elemmé alakításában meghatározó. Azonban az egészségmagatartás befolyásolására irányuló kutatások (KISS et al., 2020) megerősítik azt is, hogy a változást akaró szándék is nagyon fontos ennek a megvalósításában.

Az egészséges életmódelemek tudatos kialakításáról az egészségtudatos magatartás erősödéséről számos kutatás szól (BOROS és FEHÉR, 2020), melyek különböző célcsoportban igazolták ezt az eredményt (MARKOS és KISS, 2019). Az élelmiszerválasztásban azonban még mindig az íz (SZAKÁLY, 2008; SZAKÁLY et al., 2014), azaz az élvezeti értékek meghatározó dominanciája figyelhető meg, amely mellett ugyan az egészség is megjelenik vásárlást befolyásoló szempontként (KONTOR et al., 2018), valamint a trendek is igazolják ennek megjelenését (TÖRÖCSIK, 2014).

Európában a születéskor várható élettartam 79,2 év és az utolsó 10-15 évet mondhatjuk annak az időszaknak, amelyben a betegségek hatására csökken az életminőség. Magyarországon ezek a számok másképpen alakulnak, a férfiak születéskor várható átlagos élettartama 71,6 év, a nőké pedig átlagosan 78,7 év (SZAKÁLY, 2011). E számbeli különbségek kialakulásához hozzájárulnak azok a tények, hogy országunkban az elhízás, a cukorbetegség, a daganatos betegségek, a szív és érrendszeri problémák száma igen magas, továbbá nem fektetünk elég hangsúlyt a rendszeres testmozgásra. A sport olyan védőfaktor, amely minden életkorban alapvetően befolyásolja az életminőséget, és az élet szinte valamennyi területére hatást gyakorol (BIZE et al., 2007). A szív- és érrendszeri megbetegedések és az általuk okozott halálozás legnagyobb kockázati tényezői közé sorolhatjuk a magas vérnyomást, a cukorbetegséget, a zsíranyagcsere betegségeit, az elhízást, a dohányzást és az alkoholizmust is, valamint az egészségtelen táplálkozást és a mozgásszegény életmódot (SOÓS et al., 2011).
A másik nagyon elterjedt betegség, a cukorbetegség kialakulása elleni, elsődleges védekezés a helyes étrend összeállítása és a rendszeres testmozgás (PUSKA et al., 2003).

Ha azt szeretnénk, hogy egészséges életmódot éljünk, akkor elengedhetetlen, hogy a szabadidőnkben megjelenjen a rendszeres mozgás és a helyes táplálkozás. Szakirodalmak szerint ugyanis az egészséges életmód összetevői közé soroljuk a mentálhigiéniát, a mozgást, a táplálkozást, a pihenést, a munkát és a szórakozást. Az aktív, egészséges, hosszú élet titka az életmódban rejlik (HIDVÉGI et al., 2015).

Napjainkban a szabadidő egy fontos értékként jelenik meg, amelyben különböző aktív és passzív rekreációs tevékenységeket végeznek az emberek, a pihenés, kikapcsolódás, az egészség és munkaképesség biztosításának céljából (BORBÉLY és MÜLLER, 2008; BÍRÓ és MÜLLER, 2017). Kutatások alátámasztják azokat a tényeket, hogyha a szabadidőnkben aktívan megjelenik az egészség megőrzése, megtartása, a jó közérzet kialakítása, akkor ez hozzásegít egy egészségesebb nemzet létrejöttéhez (MÜLLER és BÁCSNÉ, 2018).

\section{ANYAg ÉS MóDSZER - MATERIAL} AND METHOD

Célunk egy olyan kvantitatív kutatás lebonyolítása, melyben az egészséges életmóddal kapcsolatban végzünk helyzetelemzést. Felmérésünk két eszköze a primer és a szekunder kutatás. Primer kutatásunk módszereként az online kérdőívezést választottuk, mivel a jelenlegi járványügyi helyzetben az emberek nem szívesen töltenek ki papír alapú kérdőíveket, továbbá a korlátozások miatt sokkal nehezebb lett volna személyesen megkérdezni őket. A kérdőívünk kitöltése az internetes közösségi oldalakon zajlott, közösségi csoportokban. Az interneten olyan csoportokat kerestünk, amelyben a sportolás, az egészség, az életmód meghatározó értékként szerepelt, melyet akár a csoport nevéből vagy a csoportot alkotó tagok céljaiból állapítottuk meg. A csoportokban megosztott kérdőív kitöltése önkéntes alapon zajlott. Főbb kérdéseink közé tartozott, hogy mennyi időt töltenek egy nap sportolással, odafigyelnek-e a helyes táplálkozásra, átlagosan mennyit isz- 
nak egy nap, egészségesnek tartják-e a jelenlegi életmódjukat. Kérdéseinkre előre meghatározott válaszlehetőségeket adtunk meg, amelyek közül mindenki azt választhatta ki, amelyik leginkább jellemző rá. A kérdőív lezárása után az adatokat Excel formában töltöttük le. A feldolgozást az SPSS matematikai-statisztikai elemző szoftver segítségével készítettük el. Alapstatisztikával mutattuk be a válaszadók különböző egyszerúbb kérdésekre adott válaszait, de alkalmaztunk chi ${ }^{2}$ próbát az összefüggések vizsgálatára az életkor és táplálkozás vonat-kozásában.

Kérdőíves kutatásunkat 225 fő töltötte ki. A demográfiai adatok a következőek: a kitöltők 61\%-a nő és 39\%-a férfi. A korosztályok a következőképpen oszlottak meg: 40,45\% 18-25 év közötti, 14,22\% 26-30 év közötti, 19,11\% 31-40 év közötti, 17,33\% 41-50 év közötti, 8,89\% pedig 50 év feletti.

A minta lakóhely szerinti megoszlása a következőképpen alakult: 50,66\%-a válaszadóknak városban, 28,44\%-a falun, 18,1\%-a megyeszékhelyen, 2,8\%-a pedig fővárosban él. Megkértük őket, hogy lakóhelyüket jellemezzék a következő választási lehetőségek alapján: csendes, tiszta környezet; zajos, szennyezett környezet; nem tudom/nem szeretnék válaszolni. A válaszok alapján 14,7\%-a a kitöltőknek zajos, szennyezett környezetben, 64,5\%-a csendes, tiszta környezetben él, 20,9\%-a pedig a nem tudom/nem szeretnék válaszolni választ adta.
Mivel kutatásunk fő témája az egészséges életmód, ezért rákérdeztünk arra, hogy menynyire fontos válaszadóinknak a saját maguk egészsége. A kutatásba résztvevő emberek 89,3\%-a azt a választ adta, hogy nagyon fontos az egészsége, 9,3\%-uk semleges választ adott, 1,3\% pedig az inkább nem fontos értékelést jelölte.

\section{EREDMÉNYEK - RESUltS}

\subsection{Testmozgással kapcsolatos eredmények - Results with Regard to Physical Activity}

A testmozgásnak számos jótékony hatása van az emberi szervezetre, amelyet már a fentiekben részleteztünk. Az emberek mozgásszegény életmódjuk mellett a sporton keresztül tudják beépíteni a mindennapjaiba a kellő testmozgást.

Kíváncsiak voltunk arra, hogy válaszadóink mennyire szeretnek sportolni. Egy egytől ötös skálán jelölhették be a válaszukat (1-nem jellemző rám, 5-nagyon jellemző rám). A legtöbb válasz a nagyon jellemző rám (52,0\%) és a jellemző rám (29,3\%) jelölés kapta. Semleges választ adott a kitöltők 12,9\%-a, 4,0\%-ra inkább nem jellemző és 1,8\%-ra nem jellemző, hogy szeret sportolni.

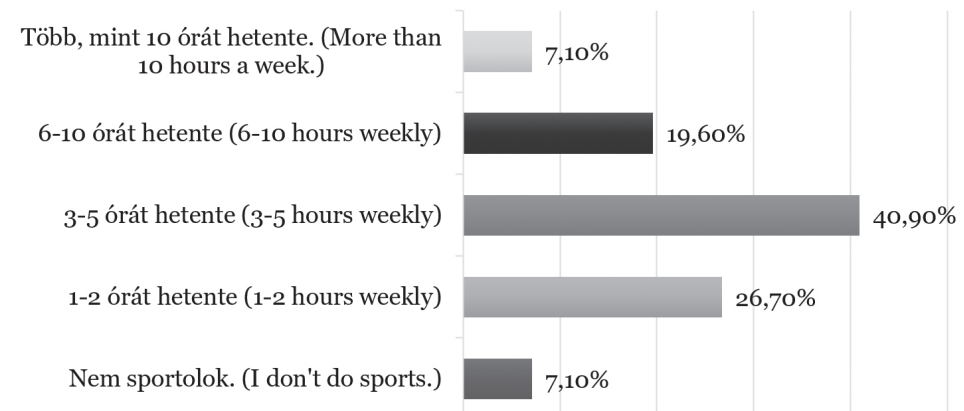

\section{1. ÁBRA}

0,00\% $\quad 10,00 \% \quad 20,00 \% \quad 30,00 \% \quad 40,00 \% \quad 50,00 \%$

FIG. 1

A válaszadók heti sportolási aránya (Weekly Sporting Habits of the Respondents)

Forrás (Source): Saját szerkesztés, 2021 (Authors'own compilation, 2021) 
Annak ellenére, hogy a kitöltők 81,3\%-a azt válaszolta, hogy szeret sportolni, mégis a kutatásunkból az látszik, hogy a válaszadók 7,10\%-a nem sportol, és 26,7\% azoknak az aránya, akik csupán heti 1-2 órát sportolnak (1. ábra). Ez összesen 48\%, azaz közel fele a válaszadóknak nem éri el a WHO által megfogalmazott ajánlást (DING et al., 2020), miszerint a 18-64 éves korosztálynak heti minimum 150 perc közepes in-tenzitású testmozgásra lenne szüksége.

Ezek az adatok azt jelentik, hogy a kitöltőink mindennapi életébe valamilyen formában és mennyiségben megjelenik a testmozgás, azonban láthatjuk, hogy még lehetne növelni a sportolással eltöltött időt és az inaktív válaszadókat sportolásra ösztönözni.

A válaszadók sportmotivációra adott feleleteiből kiderült, hogy nagy részük azért szeret rendszeresen sportolni, mert feltölti őket energiával, jobb lesz a közérzetük, valamint sokkal kiegyensúlyozottabb életet képesek élni általa. Azt sem elhanyagolható tényező, hogy a jó tár- saság képes ezeket a tulajdonságokat nagymértékben pozitív irányba befolyásolni.

\subsection{Táplálkozással kapcsolatos eredmények - Results with Regard to Dietary Habits}

Sokszor hallhatjuk azt, hogy étkezz egészségesen, fogyassz sok gyümölcsöt, zöldséget. Mit is jelent az egészséges táplálkozás valójában? E fogalom alatt a különféle ételek és italok megfelelő arányban és mennyiségben, kellő változatossággal történő rendszeres fogyasztás, amely által a betegségek kockázatát is csökkenthetjük. Egy egészséges étrendnek tartalmaznia kell a szervezetünk számára fontos energiát adó tápanyagokat, amelyek a fehérjék, zsírok, szénhidrátok és energiát nem adó tápanyagokat, amelyek a vitaminok, ásványi anyagok és nyomelemek, természetesen megfelelő menynyiségben (GYÁNI és KOHLNÉ, 2007).

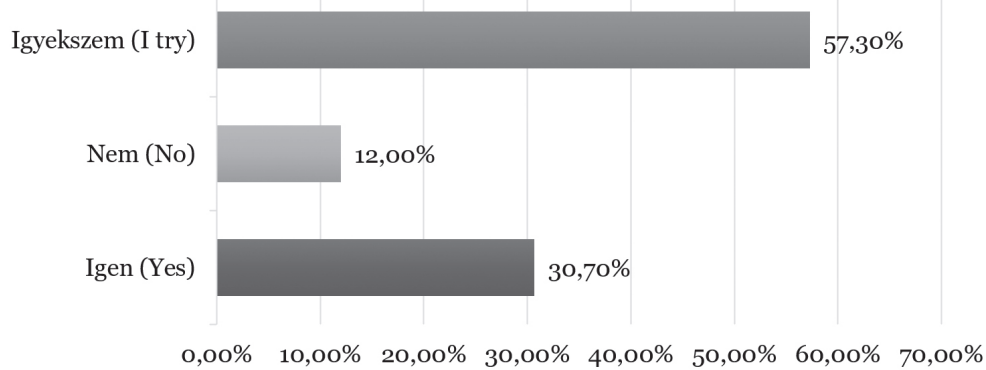

2. ÁBRA

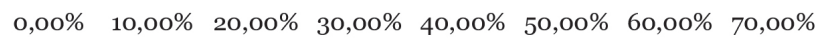

FIG. 2

\section{A kitöltők egészségtudatos, helyes táplálkozásának aránya (Health-Conscious and Healthy Dietary Habits of the Respondents)}

Forrás (Source): Saját szerkesztés, 2021 (Authors'own compilation, 2021)

A válaszadók 30,7\%-a odafigyel, míg a 57,3\%-a igyekszik odafigyelni arra, hogy sportolás mellett egészségtudatosan, helyesen táplálkozzon. A válaszadók 12\%-a azonban nem figyel oda arra, hogy helyesen étkezzen (2. ábra). A rendszeres zöldség-és gyümölcsfogyasztás a kiegyensúlyozott táplálkozás fontos összetevője. A zöldségek és gyümölcsök 75-95\% víz, azonban megfelelő forrást biztosítanak az élelmi rost szükséglet fedezéséhez, továbbá a vitaminpótlásban és ásványi anyag egyensúly fenntartásában is nélkülözhetetlenek (MEDNYÁNSZKY, 2002). A megkérdezettek 48,44\%-a naponta ötször étkezik, 74,67\%-uk minden nap fogyaszt zöldséget és gyümölcsöt, 87,11\%-nál pedig minden nap megjelennek az étkezésekben a fehérje tartalommal rendelkező élelmiszereket. Hazai kutatás megerősíti, hogy a magyar fogyasztók szeretik a zöldséget és gyümölcsöt ezért választják azt, mely igazolja a termékek iránti pozitív attitűdöt, elköteleződést (SZABÓ és LEHOTA, 2020). A zöldség és gyümölcsfogyasztást nagymértékben befolyásolja a jövedelmi helyzet is (PENCZE et al., 2007), azonban a kutatások rávilágítanak arra is, hogy a falun élők esetében a kiskertek 
és az ismerősök, barátok által biztosított zöldség és gyümölcs miatt nagyobb az egy főre jutó fogyasztás, mint a városban élő alacsony jövedelmű lakosság körében. MORTON és munkatársai (2008) szintén megerősítették, hogy az alacsony jövedelmü vidéki csoport 58\%-ának volt hozzáférése kertészeti termékekhez, míg az alacsony jövedelmű városi csoportnak csak 23\%-a számolt be hozzáférésről.

Az egészségtudatos fogyasztói magatartást (MALOTA et al., 2019) több kutatás a fiatalokra, a magasabb iskolai végzettséggel rendelkezőkre, a kedvezőbb szocioökonómiai státusszal rendelkező magasabb jövedelműekre leginkább a városokban élőkre és nemek tekintetében inkább a nőkre tartják relevánsabbnak.

Érdekes eltérés figyelhető meg abban, hogy mennyire szeretnek nassolni válaszadóink. A kérdéskört egy 1-5-ös likert skálán kellett értékelni (ahol 1= egyáltalán nem jellemző, míg az $5=$ nagyon jellemző). A 18-25 éves korosztály 52,2\%-ára, a 26-30 éves korosztály 59,4\%-ára, a 31-40 éves korosztály 47,6\%-ára inkább jellemző vagy nagyon jellemző, hogy szeret nassolni, azonban a 41-50 éves és az 50 év fölötti korosztálynál már ezek az adatok nagyon eltérnek, az ő korosztályuk 18\%-ára és 5\%-ára jellemzőek ugyanezek a kijelentések $\left(\mathrm{chi}^{2}=50,028, \mathrm{df}=16\right.$, $\mathrm{p}<0,001)$. Az eredmények azt mutatják, hogy az idősebbekre szignifikánsan kisebb mértékben jellemző a nassolás.

A vitaminfogyasztás és életkor közötti öszszefüggéseket is tapasztaltunk. Válaszadóink közül a 18-25 évesek 60,9\%-ára, a 26-30 évesek 75,1\%-ára, a 31-40 évesek 73,9\%-ára, a 41-50 évesek 79,5\%-ára, az 50 év fölöttiek pedig 95\%ára jellemző vagy nagyon jellemző, hogy vitaminokat szed $\left(\mathrm{chi}^{2}=26,769, \mathrm{df}=16, \mathrm{p}<0,05\right) \cdot \mathrm{Az}$ eredmények megerősítik, hogy az idősebbekre (50 év fölöttiek) szignifikánsan igazolható nagyobb vitaminfogyasztás a jellemző.

Az egészséges táplálkozás mellett fontos szerepet kell, hogy kapjon a megfelelö folyadékmennyiség bevitele. Több folyadékszükségleti ajánlást is találunk (JÉQUIER és CONSTANT, 2010; GANDY, 2015), összességében elmondható, hogy az ajánlott folyadékmenynyiség legalább napi 2 liter. A válaszadók 76\%a minimum 1,6 liter folyadékot iszik egy nap, azonban sajnos a válaszadók 24\%-a nem viszi be szervezetéke a napi ajánlott folyadékmenynyiséget (3. ábra).

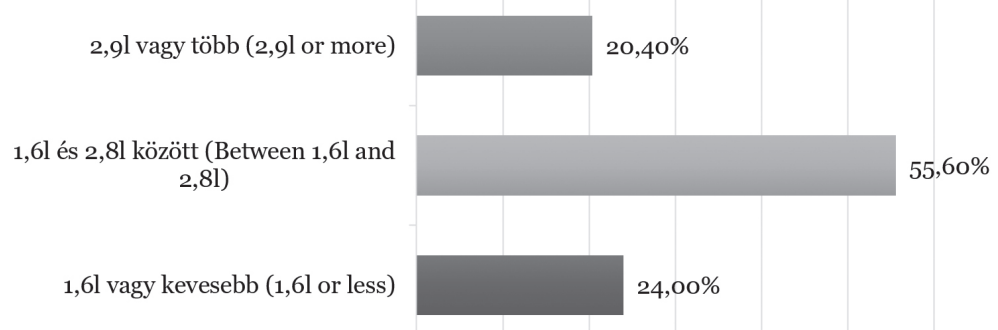

3. ÁBRA

0,00\% 10,00\% 20,00\%30,00\%40,00\%50,00\%60,00\%

A válaszadók napi folyadékmennyiség fogyasztásának aránya

FIG. 3 (Daily Fluid Intake Habits of the Respondents)

Forrás (Source): Saját szerkesztés, 2021 (Authors'own compilation, 2021) 
A kávé és tea fogyasztásról már a 90-es évek óta számos kutatás szól (SCHWARZ et al., 1994; VAN DER HOEVEN et al., 2017; KLATSKY et al., 1993; GRIGG, 2002). Mindkét ital rendszeres fogyasztásának vannak pozitív hatásai, különösen akkor, ha azt feketén, tisztán hozzáadott cukor, és egyéb ízesítők nélkül fogyasztjuk. A kutatásban részt vevő kitöltőink 63,1\%-a nem tesz cukrot a teájába, kávéjába, ami az egészségtudatosságot támasztja alá, hiszen a hozzáadott cukor mennyiségét csökkenti (4. ábra).

\section{4. ÁBRA}

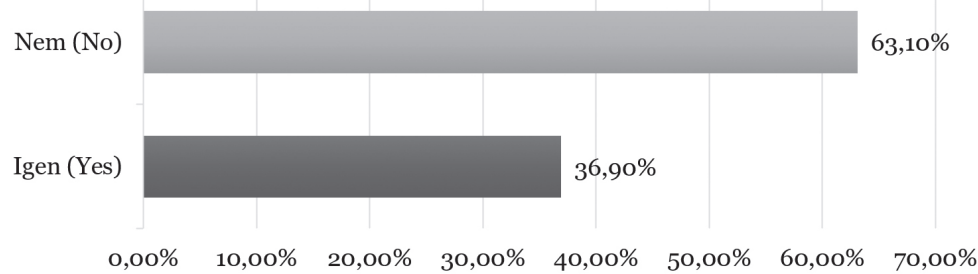

Cukorfogyasztási szokások a teában és kávéban (Sugar Consumption Habits Regarding Tea or Coffee)

Forrás (Source): Saját szerkesztés, 2021 (Authors'own compilation, 2021)

Az energiaitalok fogyasztása egyre népszerúbb (BERENCSI és FEHÉR, 2020; JASÁK és SZENTE, 2011; ORGOVÁNY, 2012; MALINAUSKAS et al., 2007). NIELSEN (2019) kiskereskedelmi mérlegéből megtudhatjuk, hogy csak Magyarországon a 2018-2019-es vizsgált időszakban, több mint 32 milliárd forint ér- tékben vásárolt a lakosság energiaitalokat, ez számszerüsítve 50 millió liternek, azaz 171 millió darab energiaitalnak felel meg. E adatok ellenére, válaszadóink nagy százaléka, pontosan $66,7 \%$-a nem fogyaszt energia italt. A rendszeres fogyasztók aránya $8,4 \%$, akik pedig néha fogyasztanak 24,9\% (5. ábra).

\section{5. ÁBRA}

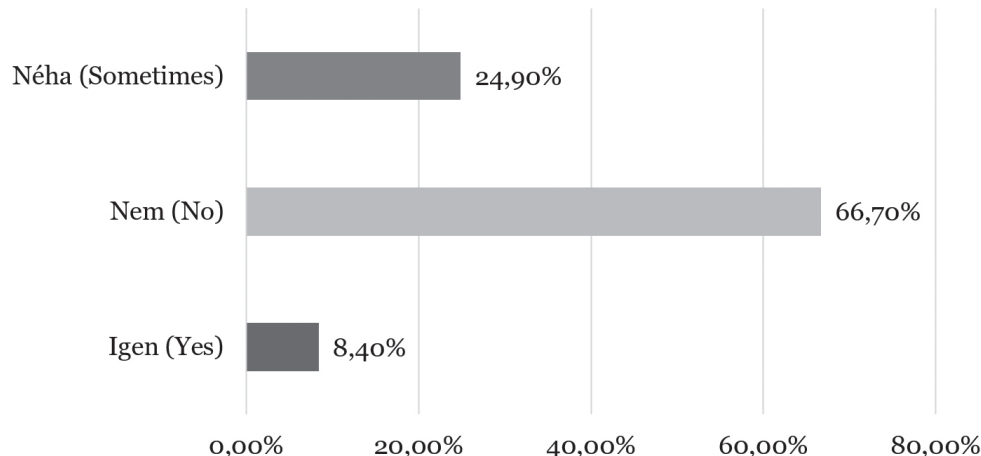

\section{Energiaital fogyasztás (Energy Drink Consumption)}

Forrás (Source): Saját szerkesztés, 2021 (Authors'own compilation, 2021)

Különbség figyelhető meg az életkorok szerint az energiaital fogyasztásában is. A 18-25 év közöttiek 57,6\%-a, a 26-30 év közöttiek 56,3\%a válaszolta azt, hogy nem fogyaszt energiaitalt, szemben a 31-40 év közöttiek 66,7\%-a, a 41-50 év közöttiek 79,5\%-a, az 50 év fölöttiek 100\%-a nyilatkozta azt, hogy nem fogyaszt energiaitalt $\left(\mathrm{chi}^{2}=24,319, \mathrm{df}=8, \mathrm{p}<0,05\right)$. Ez az eredmény a fiatalabb generáció szignifikánsan gyakoribb energiaital fogyasztását igazolta. 


\section{3. Életmóddal kapcsolatos} eredmények - Results with Regard to Lifestyle

A válaszadók 29,8\%-a teljes mértékben egyetért azzal a kijelentéssel, hogy egészséges életmódot folytat, 8,4\%-a pedig nem ért ezzel egyet, a válaszadók 61,8\%-ra részben igaz az állítás (6. ábra).
Arra kérdésre, hogy a jövőben változtatna-e a jelenlegi életmódján 27,8\%-a válaszolt egyértelmü igennel, míg a többség $61,8 \%$ csak 1-2 dolgon változtatna, $11,1 \%$ pedig teljesen elégedett a mostani életével (7. ábra).

6. ÁBRA

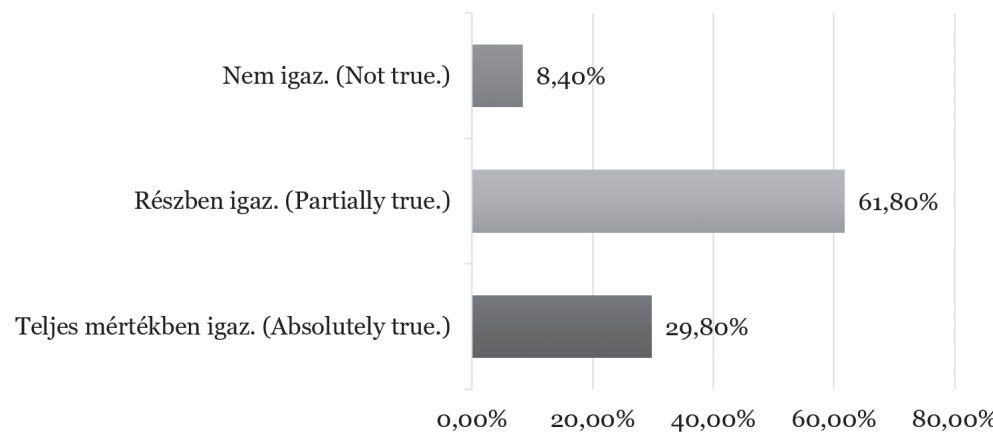

A válaszadók saját életmódjának megítélése (The Respondents Own Assumptions Regarding Their Lifestyle)

Forrás (Source): Saját szerkesztés, 2021 (Authors'own compilation, 2021)

Nem, teljesen elégedett vagyok a jelenlegi életmódommal. (No, I am completely satisfied with my lifestlye.)

Talán egy két dolgon változtatnék. (Maybe I should change one or two things.)
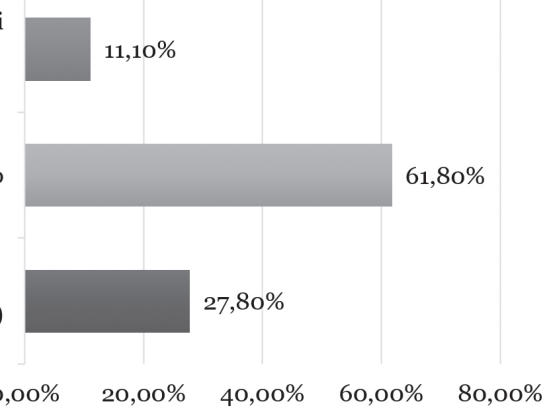

Igen, úgy érzem, hogy változtatnom kellene. (Yes, I feel like I should change.)

7. ÁBRA

$0,00 \% \quad 20,00 \% \quad 40,00 \% \quad 60,00 \% \quad 80,00 \%$

FIG. 7

Szeretnének-e változtatni a jelenlegi életmódjukon arány ("Would You Like to Change Anything About Your Current Lifestyle?")

Forrás (Source): Saját szerkesztés, 2021 (Authors'own compilation, 2021)

\section{KöVETKEZTETÉSEK ÉS}

\section{JAVASLATOK - CONCLUSIONS AND PROPOSALS}

Az egészséges életmód elemeket vizsgáló kutatásunk során az látszik, hogy a válaszadók közel fele inaktív életet él, nem éri el a WHO által megfogalmazott egészségügyi minimum értéket a heti 150 perc közepes intenzitású testmozgást. A népegészségügyi programokban a testmozgás további népszerüsítése és ösztönzése prioritást kell, hogy kapjon, hiszen még mindig alacsony a sportolók aránya.

A népesség fizikai aktivitásának és sportolásának növelésével számos egészségmutatóban, életminőségben, fittségben vagy akár testalkati mutatókban javulást érhetnénk el, 
melyet több kutatás is megerősít (MÜLLER et al., 2019; DEVITA és MÜLLER, 2020).

Az egészséges táplálkozás tekintetében azt az eredményt kaptuk, hogy a válaszadóknak csupán 48,44\%-a étkezik naponta ötször és csupán 74,67\%-uk nyilatkozta azt, hogy minden nap fogyaszt zöldséget és gyümölcsöt. A napi többszöri étkezéssel (ugyanazt a menynyiséget több felé elosztva) az anyagcsere gyorsítható és hozzájárulhat az elhízás elleni küzdelemhez. Így a többszöri étkezés életmódelemmé válásában javulni kellene, hiszen számos kutatás bemutatja, hogy a reggeli még sok esetben kimarad (LAOUES et al., 2019) a magyarok táplálkozásából. A Magyar Dietetikus Országos Szövetségének ajánlása a napi zöldség- és gyümölcsfogyasztás vagy folyadékbevitel a kutatásból láthatóan elmarad a vizsgált személyek egy részénél, azaz nem teljesül.

A felmérésből kiderül az energiaital fogyasztásának növekvő trendje, mely leginkább a fiatalabb generációra jellemző. Örvendetes, hogy a kávé és tea termékek fogyasztása során a válaszadók több mint fele nem használ hozzáadott cukrot, mely segít a kalóriabevitel csökkentésében is. A napi folyadékbevitel ajánlott mennyiségét azonban a válaszadók közel negyede (24\%) nem teljesíti.

$\mathrm{Az}$ egészségmagtartással kapcsolatos kutatás rávilágít azokra a területekre melyeket a népegészségügyi stratégiákban, munkahelyi egészségfejlesztési programokban kiemelten kell kezelni, azaz a sportolás növelése, a táplálkozási szokásokban a napi rendszeres étkezés, a napi zöldség-gyümölcsfogyasztás, vagy folyadékbevitel növelése prioritást kell, hogy kapjon, melyet más kutatások is hangsúlyoznak (BALOGH és BÁCSNÉ, 2020).

A komplex egészségszemlélet kialakítása és a komplex egészségfejlesztő programok (SLAWTA et al., 2008; CRANE et al., 2019) a hatásosak az egészségtudatos magatartás kialakításában, formálásában, hiszen a kutatásunk is megerősített abban, hogy a válaszadók 61,8\%-a nyilatkozta, hogy az egészséges életmód csak részben igaz rájuk, tehát egy-egy életmódelemben (táplálkozás, testmozgás) igaz rájuk az állítás, és 27,8\%-uk tudja is, hogy változtatnia kellene életmódján.
Kutatásunk eredményei és demográfiai adatai tükrözik azt, hogy a későbbiekben nagyobb elemszámmal is érdemes ezzel a témával foglalkozni.

\section{5. ÖSSZEFOGLALÁs - SUMMARY}

Kutatásunkban az egészséges életmódelemek közül a rendszeres testmozgás és egészségtudatos táplálkozás néhány elemére kérdeztünk rá, valamint életkori bontásban is megvizsgáltuk az eltérő válaszokat. A kutatás megerősít bennünket abban, hogy a felmért mintában a sportolás tekintetében a lakosság közel fele nem éri el a kívánt aktivitást. A táplálkozás terén még mindig kevesen vannak azok, akik napi 5-szöri étkezést részesítenek előnyben. Sajnálatos, hogy nem mindenki fogyaszt napi rendszerességgel zöldséget és gyümölcsöt. Trendként megfigyelhető az energiaital fogyasztás és a nassolás a fiatalabb generáció körében, valamint a kávé és teafogyasztásban a hozzáadott cukor elhagyása az idősebbek körében.

A magyarok kedvezőtlen egészségi állapotát ismertető kutatások és az elhízás népbetegségét ismertető tanulmányok az egészséges táplálkozás és testmozgás fókuszára helyezik a hangsúlyt (MÜLLER et al., 2018; NAGY et al., 2017). Svédországban a gyerekek körében előforduló elhízást olyan népegészségügyi programmal tudták eredményesen csökkenteni, melyben a gyerekek sportolásra fordított idejét növelték, valamint a napi zöldség és gyümölcsfogyasztás arányát növelték (SUNDBLOM et al., 2008, 2010). Magyarországon a rekreációs sportok ösztönzésével, a szabadidős sportot űzők arányának növelésével, a wellness szolgáltatásokkal és stresszoldó módszerekkel egy egészségesebb és aktívabb társadalom kialakítása valósulhat meg, mely az egészséges táplálkozás mellett szintén nagy jelentőségű a lakosság egészségmutatóban történő javulás tekintetében (HORKAY et al., 2018; BÍRÓ, 2018; BODOLAI et al., 2016; VÁCZI, 2015; BÍRÓ, 2011; MOLNÁR, 2017; LENGYEL, 2019). 


\section{KÖSZÖNETNYILVÁNÍTÁS -}

\section{ACKNOWLEDGEMENT}

A publikáció elkészítését a "GINOP-2.3.2-15-2016-00062 Életminőség fejlesztése Kelet-Magyarországon: Táplálkozás-, teljesítménybiológiai és biotechnológiai experimentális kutatások és eszközfejlesztések a humán megbetegedések megelőzésére és kezelésére" projekt támogatta.

\section{IRODALOMJEGYZÉK - REFERENCES}

Balogh, R. - Bácsné Bába, É.: The Role of Sports and Well-being Programmes in Choosing Workplaces in the Future. International Review Of Applied Sciences And Engineering. 2020. 11 (3) 280286. Paper: 00148. DOI: https://doi. org/10.1556/1848.2020.00148

Berke, Sz. - Biacs, P. - Laki Lukács, A.: A táplálkozás és a civilizációs betegségek összefüggésének fogyasztói megítélése. In: Kocziszky, Gy. (szerk.). VII. Nemzetközi Konferencia, Miskolc, GNR Szolgáltató és Kereskedelmi Bt. 2009. május 19-20., 2009

Berencsi, A. - Fehér, A.: Az energiaitalok fogyasztói és szakértői megítélésének kvalitatív elemzése. Táplálkozásmarketing. 2020. 7 (2) 51-63. DOI: https://doi. org/10.20494/TM/7/2/4

Bíró, M. - Müller, A.: Aktív pihenés, rekreáció = Active relaxation, recreation. In: Dobos, A - Mika J. (szerk.). Természeti és kulturtörténeti értékek Eger térségében $=$ Natural and cultural heritage in the Eger Region. Eger, Lícium Kiadó, 2017. 128130.

Bíró, M.: A rekreációs úszás története. rekreacio.eu 2011. 1 (1) 14-19.

Biró, M.: The Importance of Swimming and Its Positive Effects on the Health of High School Students. In: Bendíková, E. (szerk.). Physical Activity, Health and Prevention III.: International Scientific Conference: Conference Textbook. Zilina, Szlovákia, IPV Institute of Education, IPV Inštitút priemyselnej výchovy, 2018. 27-37.
Bize, R. - Johnson, J. A. - Plotnikoff, R. C.: Physical Activity Level and HealthRelated Quality of Life in the General Adult Population: A Systematic Review. Preventive Medicine. 2007. 45 (6) 401415. DOI: https://doi.org/10.1016/j. ypmed.2007.07.017

Bodolai, M. - Lívják, E. - Boda, E. - Bíró, M.: A jóga hatása a szervezetre, szerepe a stresszkezelésben. Acta Academiae Paedagogicae Agriensis Nova Series: Sectio Sport. 2016. 43 51-67.

Borbély, A. - Müller, A.: A testi- lelki harmónia összefüggései és módszertana. Valóság- Térkép- 6. PEM tanulmányok. A Professzorok az Európai Magyarországért Egyesület, Budapest. 2008. 211.

Boros, H. M. - Fehér, A.: Egészségtudatos táplálkozással kapcsolatos információforrások megítélése dietetikus szemszögból. Új Diéta: A Magyar Dietetikusok Lapja. 2020. 29 (5) 27-28.

Crane, M. - Bauman, A. - Lloyd, B. McGill, B. - Rissel, C. - Grunseit, A.: Applying Pragmatic Approaches to Complex Program Evaluation: A Case Study of Implementation of the New South Wales Get Healthy at Work Program. Health Promotion Journal of Australia: Official Journal of Australian Association of Health Promotion Professionals. 2019. 30 (3) 422. DOI: https://doi.org/10.1002/ hpja.239

Deshpande, S. - Basil, M. D. - Basil, D. Z.: Factors Influencing Healthy Eating Habits Among College Students: An Application of the Health Belief Model. Health Marketing Quarterly. 2009. 26 (2) 145-164. DOI: https://doi. org/10.1080/07359680802619834

Devita, S. - Müller, A.: Association of Physical Activity (Sport) and Quality of Life: A Literature Review. Geosport For Society. 2020. 12 (1) 44-52. DOI: https:// doi.org/10.30892/gss.1205-057 
Ding, D. - Mutrie, N. - Bauman, A. Pratt, M. - Hallal, P. R. - Powell, K. E.: Physical Activity Guidelines 2020: Comprehensive and Inclusive Recommendationst to Activate Populations. The Lancet. 2020. 396 (10265) 1780-1782. DOI: https://doi. org/10.1016/So140-6736(20)32229-7

Gandy, J.: Water Intake: Validity of Population Assessment and Recommendations. European Journal of Nutrition. 2015. 54 (2) 11-16. DOI: https://doi.org/10.1007/ s00394-015-0944-8

Gorski, M. T. - Roberto, C. A.: Public Health Policies to Encourage Healthy Eating Habits: Recent Perspectives. Journal of Healthcare Leadership. 2015. 781 .

Grigg, D.: The Worlds of Tea and Coffee: Patterns of Consumption. GeoJournal, 2002. 57 (4) 283-294. DOI: https://doi. org/10.2147/JHL.S69188

Gyáni, D. - Kohlné Papp, I.: Az egészséges étrend fogyasztói szempontjai. In: Antal, E. - Bánáti, D. - Rurik, I. - Pilling, R. Novák, K. (szerk.). Az egészséges étrend fogyasztói szempontjai. Táplálkozás, testmozgás és lélek. Fehér Könyv a TÉT Platform Egyesület kutatásainak adatai alapján. Depromo. Kft., 77-81.

Herpainé Lakó, J.: Testkultúra és családi nevelés. A családi nevelés kapcsolata az iskola testkulturális tevékenységével. In: Estefánné Varga, M. - Ludányi, Á. (szerk.). Tanárképzés, szociális képzés, gyermekvédelem: Tanulmányok a pszichológia, a neveléstudomány és a szociálpedagógia területéről. Eger, Eszterházy Károly Főiskola, 2010. 146151.

Herpainé Lakó, J.: A testi-lelki egészséget védő faktorok szerepe nagyszülők és unokáik életében. In: Karlovitz, J. T. (szerk.). 2nd IRI Health Conference, Stúrovo, 2014. December 8-9. Slovakia, Program a abstrakty. Komárno, Szlovákia, International Research Institute, 2014. 24.

Hidvégi, P. - Kopkáné Plachy, J. Müller, A.: Az egészséges életmód. EKF Líceum Kiadó, 2015
Holczer, A. J. - Kiss, V. Á.: A szülői egészségtudatosság és az étkezési preferenciáik vizsgálata a gyermekkori elhízás tükrében. Táplálkozásmarketing. 2019. 6 (2) 27-38. DOI: https://doi. org/10.20494/TM/6/2/3

Horkay, B. - Lenténé, P. A. - Biró, M.: The Supply Elements and the Recreational Possibilities in the City and in the Countryside. In: Šimonek, J. - Dobay, B. (szerk.). Sport Science In Motion: Proceedings from the Scientific Conference. Športová Veda v Pohybe: Recenzovaný Zborník Vedeckých a Odborných Prác z Konferencie. Mozgásban a sporttudomány: Válogatott tanulmányok a konferenciáról. Komárno, Szlovákia, Univerzita J. Selyeho, 2018. (340) 330339.

Jasák, H. - Szente, V.: Mérlegen az energiaital. Élelmiszer, Táplálkozás és Marketing. 2011. 8 (1-2) 61-65.

Jéquier, E. - Constant, F.: Water as an Essential Nutrient: The Physiological Basis of Hydration. European Journal of Clinical Nutrition. 2010. 64 115-123. DOI: https:// doi.org/10.1038/ejcn.2009.111

Kiss, M. - Fehér, A. - Kontor, E.: Az integrált viselkedéses modell alkalmazása az egészségmagatartás befolyásolására II. Marketing és Menedzsment. 2020. (54) (Különszám 2.: Táplálkozás, egészség, vásárlások) 65-77. DOI: https://doi. org/10.15170/MM.2020.54.KSZ.II.o6.

Klatsky, A. L. - Armstrong, M. A. Friedman, G. D.: Coffee, Tea, and Mortality. Annals of Epidemiology. 1993. 3 (4) 375-381. DOI: https://doi. org/10.1016/1047-2797(93)90064-B

Kontor, E. - Szakály, Z. - Véha, M. Kiss, M.: Egészség vagy íz? Fogyasztói dilemmák a funkcionális élelmiszerekkel kapcsolatban - Szakirodalmi áttekintés. Táplálkozásmarketing. 2018. 5 (2) 1729. DOI: https://doi.org/10.20494/ $\mathrm{TM} / 5 / 2 / 2$

Kós, K. - Herpainé Lakó, J.: A család szerepe az egészségkárosító szokások tükrében. Acta Universitatis De Carolo Eszterházy Nominatae: Sectio Sport. 2019. 46 57-69. DOI: 10.33040/ ActaUnivEszterhazySport.2019.1.57 
Laoues-Czimbalmos, N. - Müller, A. - Mező, K. - Mercs, E. - Molnár, A.: A környezeti nevelés és az egészséges életmód értékpreferenciáinak vizsgálata a „zöld” és „nem zöld” óvodába járó gyermekek szülei körében. Acta Carolus Robertus. 2019. 9 (2) 89-109. 21. DOI: https://doi.org/10.33032/acr.2019.9.2.89

Lengyel, A.: A mindfulnesz és liminalitás felértékelődése: spirituális elvonulási központok, a fenntartható jövő desztinációi? Turizmus Bulletin. 2019. 19 (1) 14-24.

Magyar Dietetikusok

Országos Szövetsége (MDOSZ): OkostányérÚj magyar táplálkozási ajánlás. http:// mdosz.hu/uj-taplalkozasiajanlasok-okostanyer/, 2021. Letöltés dátuma: 2021.11.11.

Malinauskas, B. M. - Aeby, V. G. Overton, R. F. - Carpenter-Aeby, T. - Barber-Heidal, K.: A Survey of Energy Drink Consumption Patterns Among College Students. Nutrition Journal. 2007. 26 (1) 1-7. DOI: https:// doi.org/10.1186/1475-2891-6-35

Malota, E. - Gyulavár, T. - Bogáromi, E.: „Az vagy, amit megeszel”. A hazai fogyasztók egészséges táplálkozással kapcsolatos percepciói és attitűdjei. Vezetéstudomány. 2019. 5 (1) 8088. DOI: https://doi.org/10.14267/ VEZTUD.2019.01.08

Markos, A. - Kiss, V. Á.: Az egészségtudatos életmód tényezőinek vizsgálata az amatőr férfisportolók körében. Táplálkozásmarketing. 2019. 6 (2) 6170. DOI: https://doi.org/10.20494/ $\mathrm{TM} / 6 / 2 / 6$

Mednyánszky, Zs.: Zöldség és gyümölcsfélék a sportolók táplálkozásában. Magyar Sporttudományi Szemle. 2002. 2 23-24.

Molnár, E.: Fókuszban az ifjúság: Tanulmánykötet. Szolnok, Alumni, 2017

Morton, L. W. - Bitto, E. A. - Oakland, M. J. - Sand, M.: Accessing Food Resources: Rural and Urban Patterns of Giving and Getting Food. Agriculture and Human Values. 2008. 25 (1) 107-119. DOI: https://doi.org/10.1007/s10460007-9095-8
Müller, A. - Bácsné Bába, É.: Az egészséges életmód és a sport kapcsolata. Létavértes, Magyarország: Létavértes SC '97 Egyesület, 2018

Müller, A. - Bendíková, E. - Herpainé Lakó, J. -Bácsné Bába, É. Łubkowska, W. - Mroczek, B.: Survey of Regular Physical Activity and Socioeconomic Status in Hungarian Preschool Children. Family Medicine And Primary Care Review. 2019. 21 (3) 237-242. DOI: https://doi.org/10.5114/ fmpcr.2019.88382

Müller, A. - Gabnai, Z. - Pfau, C. S. - Pető, K.: A magyarok táplálkozási szokásainak és tápláltsági állapotának jellemzői - Szakirodalmi áttekintés. Táplálkozásmarketing. 2018. 5 (2) 4555. DOI: https://doi.org/10.20494/ $\mathrm{TM} / 5 / 2 / 4$

Nagy, B. - Nagy-Lőrincz, Zs. - Bakacs, M. - Illés, É. - Sarkadi Nagy, E. - Martos, É.: Országos Táplálkozás és Tápláltsági Állapot Vizsgálat OTÁP 2014. III. A magyar lakosság makroelem-bevitele. Orvosi Hetilap. 2017. 158 (17) 653-661. DOI: https://doi. org/10.1556/650.2017.30744

Nagy, K. - Pósfai, É.: A polycystás ovárium szindrómában a táplálkozás szerepe a cukorbetegség kialakulásának megelőzésében és a terápiás lehetőségek kiegészítésében. Jelenkori Társadalmi és Gazdasági Folyamatok. 2013. 8 (1-2) 51-58. DOI: https://doi.org/10.14232/ jtgf.2013.1-2.51-58

Nielsen: 50 Millió liter energiaitallal pörgeti fel magát a Magyar. 2019. URL: https://www.nielsen.com/hu/ hu/ press-releases/2019/50-millioliterenergiaitallal-porgeti-fel-magatamagyar/ (Letöltés dátuma: 2021.02.29.)

Orgovány, A.: Huszonévesek energiaitalfogyasztási szokásai. Economica. 2012. 5 (Különszám) 113-127.

Panyor, Á.: A táplálkozás és a civilizációs betegségek kapcsolata. Jelenkori Társadalmi és Gazdasági Folyamatok. 2019. 14 (2) 99-107. 
Pecze, D. - Kiss, O. Z. - Szekely, G.: Gyümölcsfogyasztás A Jövedelem Függvényében. Gazdálkodás: Scientific Journal on Agricultural Economics. 2007. 51 (80-2016-631) 30-44. DOI: https:// doi.org/10.22004/ag.econ.57715

Puska, P. - Waxman, A. - Porter, D.: The Global Strategy on Diet, Physical Activity and Health. World Health Organization, Geneva, 2003

Schwartz, C. - Scholtens, P. A. - Lalanne, A. - Weenen, H. - Nicklaus, S.: Development of Healthy Eating Habits Early in Life. Review of Recent Evidence and Selected Guidelines. Appetite. 2011. 57 (3) 796-807. DOI: https://doi. org/10.1016/j.appet.2011.05.316

Schwarz, B. - Bischof, H. P. - Kunze, M.: Coffee, Tea, and Lifestyle. Preventive Medicine. 1994. 23 (3) 377-384. DOI: https://doi.org/10.1006/pmed.1994.1052

Slawta, J. - Bentley, J. - Smith, J. - Kelly, J. - Syman-Degler, L.: Promoting Healthy Lifestyles in Children: A Pilot Program of Be a Fit Kid. Health Promotion Practice. 2008. 9 (3) 305-312. https:// doi.org/10.1177/1524839906289221

Soós, P. - Szelid, Zs. -Bagyura, Zs. - Merkely, B.: A szív és érrendszeri megbetegedések magyarországi epidemiológiája. http://docplayer. hu/1003417-A-sziv-es-errendszerimegbetegedesek-magyarorszagi epidemiologiaja.html, 2011. (Letöltés dátuma: 2021.11.11.)

Sundblom, E. - Petzold, M. Rasmussen, F. - Callmer, E. Lissner, L.: Childhood Overweight and Obesity Prevalences Levelling Off in Stockholm but Socioeconomic Differences Persist. International Journal of Obesity. 2008. 32 1525-1530. DOI: https://doi. org/10.1038/ijo.2008.104
Sundblom, E. - Sjöberg-Jennie, A. - Lissner, B. L.: Childhood Obesity - Recent Trends in Sweden Including Socioeconomic Differences. In: O'Dea, J. A. - Eriksen, M. (szerk.). Childhood Obesity Prevention. 2010. 448.

Szabó, I. - Lehota, J.: Zöldség-gyümölcs fogyasztás vizsgálata a magyar fogyasztók körében.

Táplálkozásmarketing. 2020. 7 (2) 79-89. DOI: https://doi. org/10.20494/TM/7/2/6

Szakály, Z. - Kiss, M. - Jasák, H.: Funkcionális élelmiszerek, fogyasztói attitűdök és személyre szabott táplálkozás. Táplálkozásmarketing. 2014. 1 (1-2) 3-17. DOI: https://doi.org/10.20494/TM/1/1$2 / 1$

Szakály, Z.: Táplálkozásmarketing. Mezőgazda Kiadó, Budapest, 2011

Szakály, Z.: Trendek és tendenciák a funkcionális élelmiszerek piacán: Mit vár el a hazai fogyasztó? Élelmiszer, Táplálkozás és Marketing. 2008. 5 (2-3) 3-11.

Törőcsik, M.: Az ételfogyasztás megatrend kapcsolódásai. Táplálkozásmarketing. 2014. 1 (1-2) 19-27. DOI: https://doi. org/10.20494/TM/1/1-2/2

Váczi, P.: Labdás és golyós sportágak Révész, L. - Bíró, M. (szerk.). A rekreáció elmélete és módszertana 1. Eger, Líceum Kiadó, 2015

Van Der Hoeven, T. - Browne, J. L. Uiterwaal, C. S. - Van Der Ent, C. K. - Grobbee, D. E. - Dalmeijer, G. W.: Antenatal Coffee and Tea Consumption and the Effect on Birth Outcome and Hypertensive Pregnancy Disorders. PloS one. 2017. 12 (5) e0177619. DOI: https:// doi.org/10.1371/journal.pone.0177619

\section{JEGYZETEK $\nRightarrow$ NOTES}

